Jurnal Evaluasi dan Pembelajaran

Vol. 2 No. 1 Tahun 2020

\title{
Evaluasi Program Indonesia Pintar \\ Di Madrasah Ibtidaiyah Swasta Kecamatan Blimbing Kota Malang Dengan Model CIPPO
}

\author{
Ratih Permata Sari ${ }^{1}$, Ahmad $^{2}$ \\ Program Studi Pendidikan Anak Usia Dini, Institut Agama Islam Gondanglegi ${ }^{1}$, \\ Pascasarjana Universitas Gajayana Malang ${ }^{2}$ \\ ratihpspaud@gmail.com ${ }^{1}, \underline{\text { ahmad_t@unigamalang.ac.id }}$
}

\begin{abstract}
ABSTRAK
Penelitian evaluatif ini bertujuan untuk mengevaluasi Tata Kelola Program Indonesia Pintar (PIP) pada Madrasah Ibtidaiyah Swasta Kecamatan Blimbing Kota Malang ini sengaja menggunakan model CIPPO yang mengukur ketercapaian Program dari komponen Context, Input, Process, Product, dan Outcome. Hasil penelitian menunjukan bahwa: (1) Pemahaman pengelola PIP tentang regulasi sangat baik. (2) Tidak adanya peraturan daerah terkait yang menunjang PIP disatuan madrasah ibtidaiyah.(3) Kuota PIP yang terbatas sehingga belum memenuhi kebutuhan sasaran penerima PIP secara menyeluruh. (4) PIP tepat sasaran dengan penghasilan penerima rata-rata 500.000 per bulan. (5) Proses pendataan telah dilakukan secara berjenjang namun tidak transparan. (6) Sinergitas dan koordinasi pendataan antara unsur sekolah, aparat desa, dan Kemenag Kota Malang belum optimal.(7) Tidak ada peningkatan jumlah penerima PIP setiap tahun. (8) Adanya peningkatan jumlah keluhan masyarakat terkait mekanisme pendataan dan pencairan dana penerima PIP. (9) Belum adanya peningkatan jumlah penerima PIP memiliki KIP.(10) Adanya keterlibatan semua elemen masyarakat dalam pendistribusian KIP. (11) Tidak adanya peningkatan pelaporan hasil pendataan secara berkala dan tepat waktu setiap tahun. (12) Pengelola PIP di tingkat Kemenag Kota Malang tidak memiliki basis data PIP yang secara terbuka dapat diakses oleh masyarakat. (13) Sosialisasi belum berjalan dengan baik. (14) Koordinasi antara Kemenag Kota Malang, pihak sekolah, dan lembaga yang mencairkan dana PIP berjalan dengan baik. (15) Pencairan dana PIP tidak tepat waktu, (16) Belum adanya peningkatan kegiatan monitoring dan evaluasi PIP dengan melibatkan lembaga independent.(17) PIP tidak berdampak terhadap prestasi belajar siswa. (18). PIP tidak berdampak positif terhadap kompetensi akademik dan non akademik siswa. (19) Adanya peningkatan kepuasan pengelola terhadap pelaksanaan PIP. (20) Tidak semua pemilik KIP menerima bantuan dana PIP untuk menunjang operasional pendidikan. (21) Tidak adanya peningkatan jumlah penerima dana PIP setiap tahun baik dalam satu jenjang pendidikan maupun lintas jenjang pendidikan. (22) Meningkatnya angka partisipasi sekolah anak usia 6-12 tahun di Kota Malang.
\end{abstract}

Kata kunci. Program indonesia pintar, PIP, CIPPO

\section{PENDAHULUAN}

Program Indonesia Pintar disingkat PIP merupakan program prioritas pemerintah untuk menunjang dan menuntaskan Program Wajib Belajar 12 tahun, yang diperuntukkan bagi anak Indonesia usia 6-21 tahun baik yang sedang menempuh pendidikan di Satuan Pendidikan Formal, Satuan Pendidikan Nonformal dan Satuan Pendidikan Informal, maupun anak usia 621 tahun yang belum sekolah supaya mendapatkan kesempatan untuk sekolah. Sebagaimana ruh NAWACITA Nomor 5 Pemerintahan Presiden Joko Widodo dan Wakil Presiden Muhammad Yusuf Kalla yakni Meningkatkan Kualitas Hidup Manusia dan Masyarakat Indonesia, dalam pelaksanaannya diatur dalam Instruksi Presiden Nomor 7 Tahun 2014.

Instruksi tersebut mengamanatkan kepada Kementerian Pendidikan dan Kebudayaan melalui Dinas Pendidikan Provinsi, Kabupaten, dan Kota Madya seluruh Indonesia. Tidak terkecuali Dinas Pendidikan Kota Malang untuk melakukan pendataan, pengorganisasian, dan penyaluran PIP pada siswa di Tingkat Pendidikan Dasar dan Pendidikan Menengah Pertama bekerjasama dengan seluruh stakeholders yang ada supaya PIP bermanfaat bagi masyarakat.

Sebagaimana telah diatur dalam Undang-Undang Nomor 23 tahun 2014 tentang Pembagian Peran Antara Pemerintah Pusat, Provinsi, dan Kabupaten, Kota Madya bahwa Pendidikan Dasar dan Pendidikan Menengah Pertama telah menjadi kewenangan pemerintah Kabupaten dan Kota Madya, sedangkan pemerintah Provinsi hanya mengelola Pendidikan 
Menengah Atas dan Menengah Kejuruan. Adanya perubahan kewengan tersebut berimplikasi pada beragamnya penafsiran dan kebijakan pemerintah daerah itu sendiri dalam sistem pendataan, tata organisasi dan atribut pelaksanaan PIP di daerah.

Data tahun akademik 2015/2016, menunjukkan bahwa populasi peserta didik yang menjadi tanggungjawab Dinas Pendidikan Kota Malang sebanyak 125.067 (14\%) dari 881.794 orang penduduk yang tersebar dari 5 Kecamatan dan 57 Kelurahan, dengan rincian seperti pada gambar 1 berikut:

Peserta Didik di Kota Malang

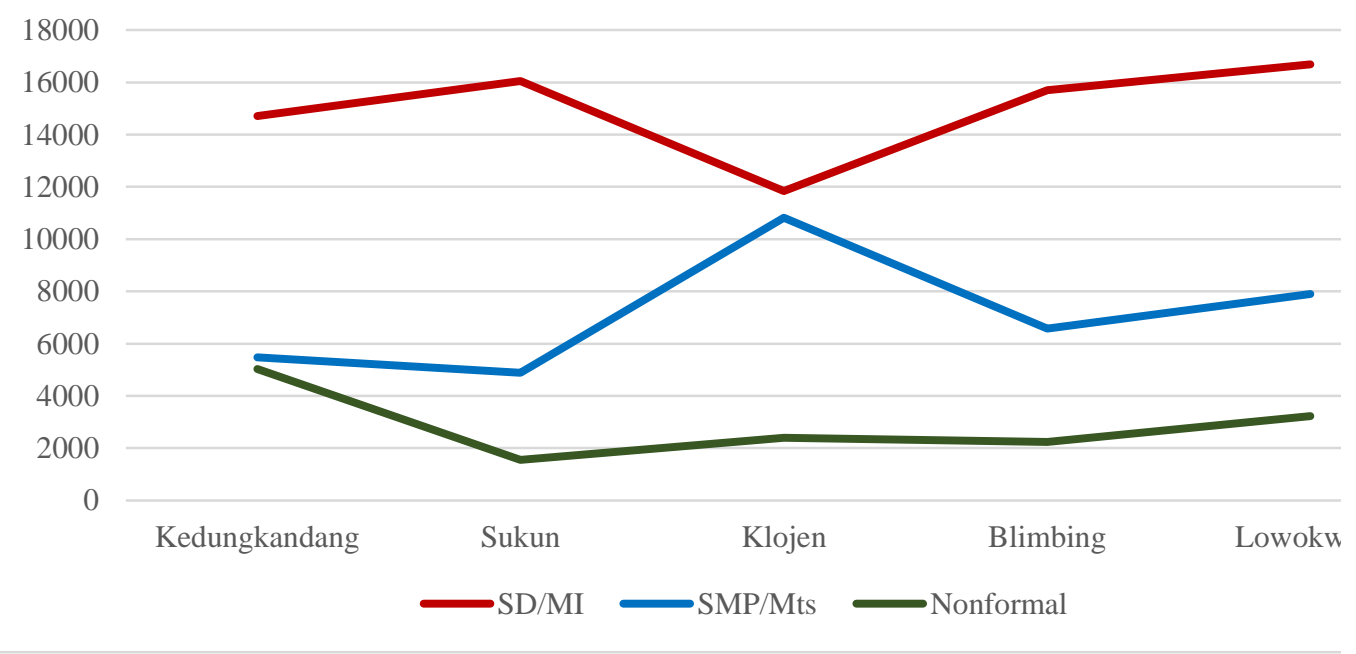

Sumber: Data Hasil Olah Penulis yang bersumber dari BPS dan Disdik Kota Malang Tahun 2015/2016.

\section{Gambar 1. Peserta Didik di Kota Malang}

Mencermati data di atas, dapat diasumsikan bahwa populasi target penerima PIP di Kota Malang pada Tingkat Satuan Pendidikan Dasar sebesar 60\%, Tingkat Pendidikan Menengah Pertama 29\%, dan pada Tingkat Pendidikan Nonformal (Pendidikan Masyarakat) sebesar $12 \%$, bahkan setiap tahun akan mengalami penurunan sesuai dengan tingkat keterserapan dan realisasi program di masyarakat. Namun pada kenyataannya, realisasi PIP banyak ditemukan masalah dimasyarakat terutama terkait masalah keterserapan anggaran sesuai dengan target alokasi penerima dana PIP.

Berdasarkan data yang dikutip pada harian Lingga Pos Edisi 4 September 2017 bahwa Kementerian Pendidikan dan Kebudayaan telah mengalokasikan dana PIP untuk 13.356.424 anak dari total target 17.927.308 anak penerima PIP tahun 2017, namun dari target tersebut, baru tersalurkan 16,78\% (2.251.586 anak). Rendahnya capaian target penerima PIP tahun 2017, disebabkan oleh beberapa faktor antara lain: (1) Lemahnya sistem pendataan yang berdampak pada akurasi dan validitas data yang dipakai sebagai dasar pemberian Kartu Indonesia Pintar/KIP, (2) Adanya multitafsir terhadap kriteria miskin sebagai syarat penerima PIP, (3) Pendistribusian KIP terlambat, (4) Metode penyaluran dana PIP yang relatif lama, karena koordinasi antara pemerintah pusat, pemerintah daerah, satuan pendidikan dengan lembaga penyalur yang terkesan lama dan berbelit, serta (5) Sosialisasi tujuan dan manfaat PIP belum optimal dan berbagai permasalahan teknis dan praktis lainnya yang terjadi dalam pelaksanaan PIP.

Sebagai Program Strategis Nasional yang menggunakan kucuran dana APBN yang sangat besar, PIP bertujuan untuk meningkatkan kualitas pendidikan masyarakat yang tergolong miskin dan rentan miskin, idealnya bisa berjalan dengan baik dan relevan untuk 
mencapai standar ketersediaan, keterjangkauan, kesetaraan, dan pendidikan yang berkeadilan bagi masyarakat diperlukan langkah evaluatif terhadap implementasi Tata Kelola Program Indonesia Pintar.

Implikasi dari PIP tahun 2019 adalah terjadinya peningkatan kualitas, kuantitas, serta pendidikan yang berkeadilan bagi masyarakat, sebagimana telah dituangkan pada Rencana Strategis Kementerian Pendidikan dan Kebudayaan tahun 2015-2019 dengan target meningkatkan Angka Partisipasi Pendidikan Dasar dan Pendidikan Menengah tahun 2019 dengan rincian sebagai berikut.

\begin{tabular}{llcc} 
& \multicolumn{3}{c}{ Tabel 1. APM Jenjang Sekolah } \\
\hline \multirow{2}{*}{ Indikator Kinerja } & \multicolumn{2}{c}{ Kondisi Awal dan Target Capaian } \\
\cline { 2 - 4 } & Tahun 2014 & Tahun 2019 \\
\hline 1. APM SD/MI & $91,3 \%$ & $94,8 \%$ \\
2. APK SD/MI/SDLB/Paket A & $111,0 \%$ & $114,1 \%$ \\
3. & APM SMP/MTs & $79,4 \%$ & $82,0 \%$ \\
4. & APK SMP/MTs/Paket B & $101,6 \%$ & $106,9 \%$
\end{tabular}

Sumber Data: Renstra Kemdikbud, 2015.

Melihat data di atas, pemerintah sangat optimis untuk menuntaskan Pendidikan Dasar dan Menengah Pertama di Indonesia melalui optimalisasi Program Indonesia Pintar. Hal ini cukup mendasar karena perhatian Indonesia sebagai bangsa modern dengan memperkuat investasi sumber daya manusianya. Kajian ini sebagai emrio atau permulaan untuk menelaan Efektivitas Pelaksanaan Program Indonesia Pintar secara Nasional mulai dari aspek Perencanaan sampai pada aspek Dampak PIP bagi Masyarakat dalam bentuk penelitian Strategis Nasional dalam 5 tahun mendatang.

Kajian ini pula, tentu dilatarbelakangi rasa ingin tahu peneliti terhadap dampak dari hasil penelitian yang telah dilakukan oleh Staf Ahli Mendikbud Bidang Sosial dan Ekonomi Pendidikan dengan judul Optimalisasi Potensi Lembaga Pemberi Beasiswa (2013), yang dimana hasil kajian tersebut telah menemukan masalah baru dalam pelaksanaan Bantuan Siswa Miskin disingkat BSM penelitian diantaranya: (1) Pemilik KPS sebagai sarana program BSM sangat minim menerima bantuan BSM, (2) Sosialisasi program BSM sangat kurang baik oleh pelaksana ditingkat pusat sampai ke masyarakat, (3) Pengumpulan data siswa miskin belum terwujud, (4) Kinerja lembaga penyalur BSM belum baik, (5) alokasi kuota jumlah penerima BSM pada satuan pendidikan belum sesuai dengan kebutuhan yang ada, dan (6) terdapat $48,5 \%$ penerima BSM mengatakan bahwa menerima dana bantuan tidak utuh sesuai besaran yang tercantum dalam panduan.

Untuk memperoleh gambaran lengkap tentang PIP, diperlukan kajian lebih mendalam khususnya berkaitan dengan Manajemen Program Indonesia Pintar yang dibatasi pada manajemen PIP yang dikelola Kantor Kementerian Agama Wilayah Kota Madya Malang sebagai tempat penelitian. Tujuan akhir dari kajian Manajemen Program Indonesia Pintar untuk memberi masukan atau rekomendasi bagi penyusunan kebijakan perencanaan dan penganggaran sehingga dapat memberikan dampak pada aspek pemerataan, tepat sasaran, tepat jumlah, tepat waktu, dan berkelanjutan, serta berdampak pada prestasi bagi penerima PIP. Kajian ini juga dilakukan dalam rangka memetakan Peningkatan Angka Partisipasi Kasar dan Penurunan Angka Putus Sekolah di tingkat Satuan Pendidikan Madrasah Ibtidaiyah di Kota Madya Malang.

Berdasarkan latar belakang penelitian di atas, maka objek penelitian ini adalah Program Indonesia Pintar pada Tingkat Madrasah Ibtidaiyah, difokuskan pada tata kelola PIP serta upaya-upaya yang telah dilakukan oleh pengelola program dalam peningkatan kualitas dan kuantitas PIP di Kota Malang dengan menggunakan model evaluasi Context, Input, Process, Product, dan Outcome (CIPPO). 
Evaluasi dipandang sebagai suatu proses pemberian nilai secara sistematis terhadap suatu program atau kegiatan mulai dari perencanaan, pengumpulan data, analisis data sampai memberikan laporan berdasarkan kriteria yang telah ditetapkan untuk membantu dalam pengambilan keputusan. Stufflebeam dan Shinkfield (2007: 4) mendefinisikan "Evaluation is a process for giving attestations on such matters as reliability, effectiveness, costeffectiveness, efficiency, safety, ease of use, and probity". Alkin (2011: 9) mendefinisikan evaluation is judging the merit or worth of an entity.

Jadi, evaluasi merupakan suatu kegiatan dilakukan secara sistematis dan berkesinambungan mulai dari aktivitas perencanaan, identifikasi informasi, pengumpulan informasi, klarifikasi informasi, menganalisis informasi sampai menghasilkan laporan melalui pemberian nilai pada suatu objek seperti program, kebijakan, kinerja personal berdasarkan kriteria standar yang telah ditetapkan dengan tujuan membantu stakeholders dalam pengambilan keputusan, mendukung akuntabilitas dalam penerapan kegiatan secara efektif dan meningkatkan pemahaman tentang tujuan pengembangan suatu objek yang dievaluasi.

Berdasarkan konsep tersebut, evaluasi program merupakan suatu pendekatan yang digunakan untuk menilai efektivitas suatu objek (program, projek, kebijakan, kinerja, hasil dan lainnya) untuk membantu dalam pengambilan keputusan apakah suatu objek tersebut perlu diteruskan, dan dihentikan. Manfaat dari proses evaluasi ini untuk membantu pemangku kepentingan dalam merencanakan dan mengalokasikan anggaran program, penetapan pelaksanaan, dan hasil yang dicapai dari proyek, kebijakan, maupun program sehingga dapat menetapkan langkah strategis dalam pemenuhan tujuan yang ditetapkan.

Banyak model evaluasi program yang dikembangkan oleh para ahli sesuai dengan tujuan, pendekatan, metodologi, dan nilai dari model tersebut. Tolla (2014: 237) memandang banyaknya ragam model evaluasi program dewasa ini sesuai dengan era perkembangannya, mulai dari model evaluasi program yang dikembangkan Madaus dan Kellaghan (1992) sampai evaluasi program pendekatan Stufflebean (2000). Dalam penggunaannya secara substansi manfaatnya sama yakni sebagai pisau analisis untuk menghasilkan rekomendasi dari program yang dievaluasi, adapun terjadinya perbedaan dilapangan dipengaruhi oleh model dan cara pandang yang digunakan oleh para ahli tersebut. Hal ini senada dengan pendapat Fitzpatrick, Sanders, dan Worthen (2004: 9) bahwa keragaman model evaluasi yang ada sebagai akibat dari keragaman tujuan secara filosofis, penerapan preferensi metodologis yang berbeda, dan kebutuhan praktis dari ahli yang berbeda-beda.

Atas dasar kebutuhan dan preferensi metodologis tersebut, maka penelitian ini sengaja menggunakan evaluasi program model CIPPO, merupakan model yang berorientasi kepada pengambilan keputusan manajemen dengan tujuan untuk membantu pemerintah sebagai pemilik program dalam membuat kebijakan. Model ini membagi evaluasi dalam lima macam, yaitu: (1) Evaluasi Konteks untuk memetakan rancangan keputusan ditinjau dari aspek regulasi, dan tujuan dari program yang dikembangkan. (2) Evaluasi Masukan untuk menstrukturkan keputusan dengan menentukan sumber-sumber yang tersedia, langkah yang dilakukan terhadap rencana dan strategi untuk mencapai kebutuhan PIP, serta bagaimana prosedur kerja untuk mencapai tujuan PIP. (3) Evaluasi Proses dilakukan untuk mengetahui efektivitas implementasi kebijakan oleh pengelola dan mengukur realisasi rencana program telah dilaksanakan. (4) Evaluasi Produk digunakan untuk memberikan pertimbangan dalam perubahan kebijakan, baik dalam bentuk data capaian dan langkah strategis yang dilakukan kedepan, dan (5) Evaluasi Dampak yakni suatu kegiatan yang menyediakan informasi mengenai dampak yang dicapai dari PIP dibandingkan dengan hasil yang diharapkan.

Dalam pelaksanaannya, PIP sangat membantu dalam peningkatan kapasitas dan kapabilitas masyarakat yang barang tentu perlu dilakukan evaluasi kinerjanya. Cynthia D. 
Fisher, Lyle F. Schoefeldt, dan James B. Shaw dikutip Wirawan (2009: 12), Bahrul Kirom (2012: 54), Simanjuntak (2011:107) mendefinisikan evaluasi kinerja sebagai instrumen untuk menilai aktifitas sebuah manajemen program sebagai referensi dalam proses pengambilan kebijakan yang dilakukan secara bertahap mulau dari tahap perencanaan, pemantauan, pelaksanaan, pengawasan, ataupun pertanggungjawaban.

Kerangka konseptual menunjukkan bahwa unsur-unsur yang dinilai dalam kinerja program suatu organisasi, yaitu berupa data, informasi, dan laporan yang berisi tentang capaian hasil kegiatan, ketepatan sistem yang digunakan, proses pelaksanaan, ketepatan kebijakan yang diterapkan serta akuntabilitas kelembagaan.

Dengan demikian, evaluasi kinerja dapat dikatakan sebagai suatu pendekatan yang digunakan dalam proses penilaian terhadap pelaksanaan tugas unit-unit kerja dalam satu organisasi sesuai dengan standar kinerja yang telah ditetapkan.

\section{METODE PENELITIAN}

Penelitian evaluatif ini dilakukan di Madrasah Ibtidaiyah Swasta dibawah Koordinasi kantor Kemenag Kota Malang. Model CIPPO (Context, Input, Process, Product, dan Outcome), digunakan untuk mengetahui manajemen program. Subyek penelitian terpilih 26 orang yang mewakili unsur Pengelola PIP di Kemenag, Pengelola PIP di Satuan Pendidikan, peserta didik penerima bantuan PIP, dan Orang Tua siswa Penerima PIP. Data dikumpulkan dengan menggunakan kuesioner dan wawancara kemudian dianalisis secara deskriptif kualitatif dengan menggunakan pendekatan miles and huberman.

\section{HASIL PENELITIAN DAN PEMBAHASAN}

\section{Komponen Konteks}

\section{Pemahaman terhadap Regulasi tentang PIP}

Program Indonesia Pintar merupakan bentuk layanan pemerintah kepada masyarakat miskin atau kurang mampu sebagai penyempurnaan dari program bantuan siswa miskin (BSM). Dalam perjalannya, PIP mengacu pada Instruksi Presiden Republik Indonesia Nomor 7 Tahun 2014 tentang Pelaksanaan Program Simpanan Keluarga Sejahtera, Program Indonesia Pintar, dan Program Indonesia Sehat untuk Membangun Keluarga Produktif. dan Peraturan Presiden Republik Indonesia Nomor 166 Tahun 2014 tentang Program Percepatan Penanggulangan Kemiskinan, secara implisit dijelaskan dalam Pasal 4, Peraturan Presiden Nomor 166 Tahun 2014, dalam pelaksanaan program perlindungan sosial, Pemerintah menerbitkan kartu identitas bagi penerima program perlindungan sosial, yaitu; Kartu Keluarga Sejahtera (KKS) untuk penerima Program Simpanan Keluarga Sejahtera, Kartu Indonesia Pintar (KIP) untuk penerima Program Indonesia Pintar, dan Kartu Indonesia Sehat (KIS) untuk penerima Program Indonesia Sehat. Ketiga program di atas ditujukan untuk mempercepat penanggulangan kemiskinan di Indonesia.

Regulasi PIP yang menjadi acuan di lingkungan kementerian agama tersendiri mengacu pada Keputusan Menteri Agama nomor 258 tahun 2015 tentang Pedoman Program Indonesia Pintar Pada Pendidikan Keagamaan Islam, dan secara operasional termaktup dalam Keputusan Direktur Jenderal Pendidikan Islam Nomor 4802 Tahun 2015 tentang Petunjuk Teknis Program Indonesia Pintar pada Pendidikan Keagamaan Islam yang kemudian diubah melalui Keputusan Direktur Jenderal Pendidikan Islam Nomor 1781 tahun 2019 tanggal 28 Maret 2019. Supaya keputusan tersebut sampai di pengelola PIP ditingkat satuan pendidikan maka Direktu Jenderal Pendidikan Islam menerbitkan surat Nomor B. 1532.2/DJ.I/Dt.I.I/PP.00/04/2019 tertanggal 02 April 2019 tentang Penyampaian Petunjuk Teknis Pelaksanaan Bantuan Sosial Program Indonesia Pintar Tahun 2019. Petunuk teknis tersebut merupakan produk rancangan dari Direktorat Kurikulum Sarana, Kelembagaan dan Kesiswaan dengan tujuan agas kepala kantor 
wilayah kementerian agama provinsi di seluruh Indonesia segera mensosialisasikan pedoman tersebut ke kantor kementerian agama kabupaten/kota.

Hasil penelitian menunjukkan bahwa penyampaian informasi terkait regulasi, petunjuk teknis dan petunjuk pelaksanaan tentang PIP dipahami dengan baik oleh pengelola PIP ditingkat Kantor Kementerian Agama Kota Malang beserta pengelola PIP ditingkat satuan Madrasah Ibtidaiyah. Hal ini dapat dibuktikan dengan tingginya usulan PIP di satuan MI Swasta, dan berbanding terbalik dengan usulan PIP di satuan MI Negeri yang mengalami penurunan setiap tahun. Keadaan yang cukup berbeda ini dilatarbelakangi bahwa sebaran sasaran siswa yang layak terima bantuan PIP di satuan MI Negeri relatif sedikit dibandingkan dengan di satuan MI Swasta. Disamping itu, adanya penolakan dari satuan MI tertentu dikarenakan bantuan alokasi dana PIP relatif kecil bila dibandingkan dengan biaya operasional sekolah yang haarus ditanggung oleh satuan MI sehingga satuan MI memilih untuk mengoptimalkan peran serta masyarakat.

Sebagaimana kutipan wawancara dengan pengelola PIP di Kantor Kementerian Agama Kota Malang mengatakan bahwa:

“...satuan MI yang favorit biasanya jumlah usulan penerima PIP-nya sedikit, hal ini disebabkan karena sasaran penerima PIP di sekolah tersebut relatif sedikit, dan disisi lain, kebutuhan biaya operasional pendidikan yang relatif tinggi sedangkan dana bantuan pemerintah relatif kecil jika dibandingkan dengan kebutuhan yang ada..."

Dari informasi tersebut menunjukkan bahwa pengelola PIP ditingkat Kantor Kemenag Kota Malang dan Satuan Pendidikan memahami tentang regulasi PIP. Indikator lainnya adalah hasil tanggapan dari responden menunjukkan bahwa $100 \%$ responden sepakat bahwa pengelola mengetahui arah pengembangan PIP yang relevan dengan kebutuhan daerah, karena dengan program PIP cukup membantu kebutuhan anak-anak yang tidak mampu yang lebih khusus belajar di sekolah swasta yang masih umumnya membutuhkan infaq dari masyarakat.

Dari aspek dukungan pemerintah daerah, karena pengelolaan PIP di Kemenag Kota Malang, maka pemerintah daerah tidak mengeluarkan perda khusus, namun perda yang diterbitkan adalah sekolah-sekolah yang dibawah tanggungjawab pemerintah kota Malang terkait sekolah gratis. Temuan penelitian ini relevan dengan hasil tanggapan responden yang berasal dari pengelola PIP baik dari Kemenag Kota Malang maupun dari pengelola PIP ditingkat satuan MI bahwa terdapat $50 \%$ responden menyatakan pemerintah daerah menerbitkan perda terkait dana untuk menunjang PIP, dan masing-masing $25 \%$ menyatakan setuju dan tidak tahu. Mengacu pada hasil penelitian tersebut dapat disimpulkan bahwa secara spesifik pemerintah daerah belum menerbitkan Perda tentang penguatan PIP di lingkungan Kemenag Kota Malang, adapun Perda yang diterbitkan adalah berkaitan dengan sekolah gratis sebagai bentuk komitmen janji politik Wali Kota dan Wakil Wali Kota Malang.

\section{Ketercapaian Tujuan}

Program Indonesia Pintar merupakan program unggulan pemerintah untuk mensejahterakan, mensejajarkan kualitas hidup masyarakat Indonesia melalui subsidi pembiayaan pendidikan. Semangat ini diketahui secara umum oleh masyarakat yang berada dilevel madrasah Ibtidaiyah. Sebagaimana hasil wawancara dengan responden dari Kemenag Kota Malang menyatakan bahwa "PIP ini sangat diketahui oleh masyarakat dengan tujuan memberikan subsidi pendidikan bagi masyarakat yang masuk kategori miskin". Hal ini sangat konsisten dengan jawaban Responden dari Pengelola PIP ditingkat Madrasah, wali murid, bahkan siswa sendiri yang pada kesimpulannya bahwa: 
Jurnal Evaluasi dan Pembelajaran

Vol. 2 No. 1 Tahun 2020

“...PIP bertujuan untuk memberikan bantuan pendidikan bagi masyarakat miskin yang dibuktikan dengan Kartu Indonesia Pintar, Kartu Keluarga Sejahtera”

Berdasarkan hasil penelitian di atas, maka dapat dikatakan bahwa PIP sangat diketahui oleh masyarakat dengan alokasi Kuota belum sesuai dengan kebutuhan masyarakat. Namun, khusus madrasah negeri jumlah pendaftar PIP sangat kecil dengan persentasi di bawah $1 \%$. Sebagaimana hasil wawancara dengan pengelola PIP Kantor Kemenag Kota Malang sebagai berikut:

“...sejak tahun 2018 sampai sekarang, kuota penerima PIP ditingkat satuan madrasah mengalami penurunan dibandingkan tahun-tahun sebelumnya padahal masyarakat masih banyak yang membutuhkan"

Hasil wawancara di atas memberikan gambaran kepada kita bahwa masyarakat membutuhkan PIP, akan tetapi dengan adanya kebijakan kuota PIP ditentukan oleh pemerintah pusat maka penerima PIP cenderung turun padahal setiap tahun usulan penerima PIP meningkat. Walaupun demikian, tanggapan dari responden terhadap penentuan kuota penerima PIP oleh pemerintah Pusat ditanggapi secara positif oleh masyarakat, terbukti bahwa terdapat $50 \%$ responden menyetujui bahwa penentuan kuota penerima PIP dilakukan oleh pemerintah pusat, sedangkan sisanya masing-masing $25 \%$ pengelola PIP ditingkat satuan madrasah raguragu dalam menjawab dan menyatakan tidak setuju.

Berdasarkan data penerima PIP tahun 2019, Kemenag Kota Malang mendapat kuota sebanyak 696 penerima PIP yang tersebar dari 49 MI dengan rincian 2 MI Negeri dan 47 MI swasta, dengan rata-rata penerima PIP sebanyak 2,04\%. Sedangkan di kecamatan Blimbing MI yang mendapat kuota penerima PIP terbanyak adalah MIS KH Hasym Asyari sebesar 27,84\%, dan tersedikit adalah MIS KH. Badrussalam sebesar 6,19\% dengan sebaran seperti ditunjukkan dengan gambar berikut:

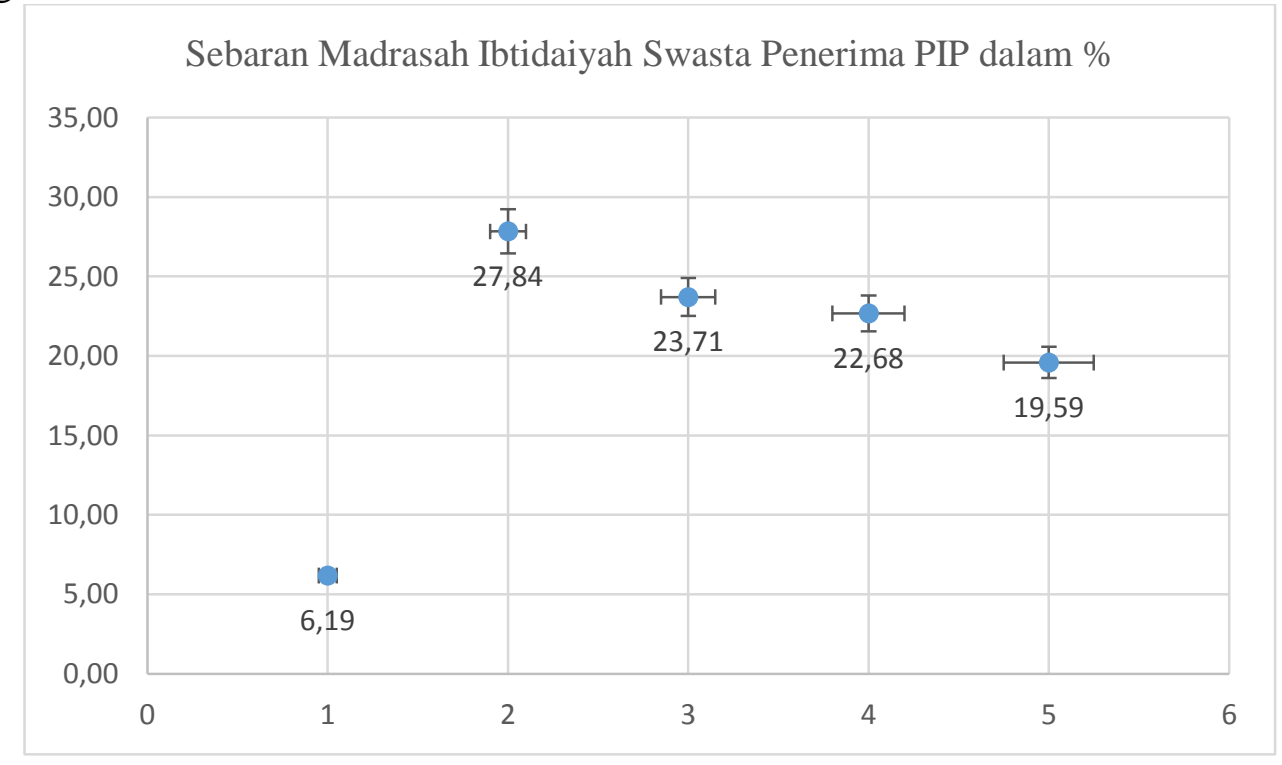

Gambar 2. Sebaran MIS Penerima PIP Tahun 2019

Indikator lain untuk mengukur ketercapaian tujuan PIP adalah dengan mengidentifikasi sasaran PIP. Hasil penelitian menunjukkan bahwa $100 \%$ orang tua dan siswa sama-sama sepakat mengatakan bahwa penerima PIP selama ini sesuai dengan sasaran PIP, dengan kriteria bahwa penghasilan orang tua siswa rata-rata dibawah 500.000/bulan, bahkan ditemukan penerima PIP berasal dari keluarga yang sangat miskin dengan status yatim piatu. 
Jurnal Evaluasi dan Pembelajaran

Vol. 2 No. 1 Tahun 2020

\section{Komponen Masukan}

\section{Mekanisme Pendataan PIP}

Berdasarkan hasil wawancara dengan pengelola PIP di Kantor Kemenag Kota Malang tidak melakukan pendataan secara langsung ke rumah tangga penerima PIP. Hal ini disebabkan proses pendataan terkait PIP dilakukan oleh Kementerian Sosial Republik Indonesia bekerjasama dengan TNP2K. Informasi ini sangat berbeda dengan tanggapan dari pengelola PIP ditingkat satuan MI bahwasebanyak 75\% menjawab bahwa sumber data acuan PIP berasal dari data EMIS Kemenag, dan 25\% sisanya berasal dari Kemenso, seperti data berikut:

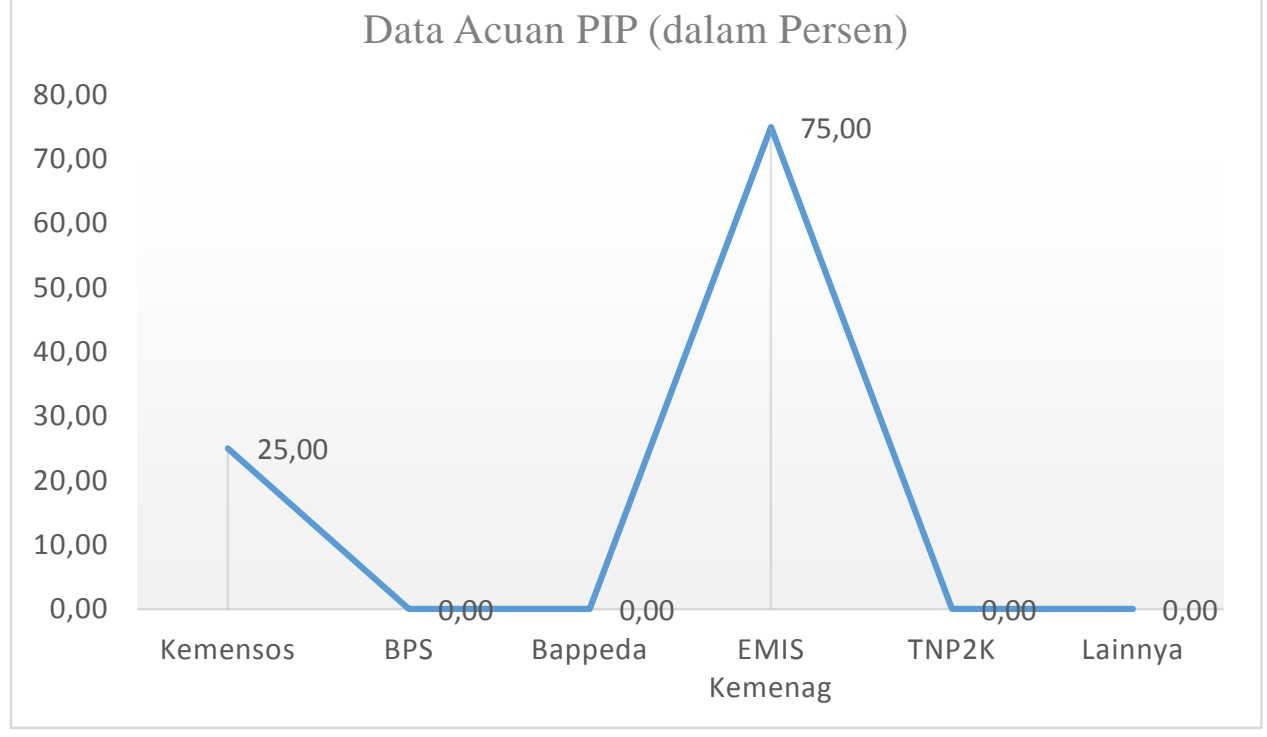

Gambar 3. Sumber Data Acuan PIP

Berdasarkan informasi tersebut, dapat diasumsikan bahwa adanya kesimpangsiuran informasi terkait sumber data acuan pengajuan penerima PIP. Kondisi ini cukup berbeda ketika pengelolaan PIP sepenuhnya menjadi kewenangan Kemenag Kota Malang. Terkadang didapati sekolah kesulitan mengidentifikasi siswa penerima kartu PIP karena penentuan kategori penerima PIP ditentukan oleh pemerintah pusat melalui keikutsertaan unsur kelurahan sekaligus biasanya distribusi kartu indonesia pintar dan kartu keluarga harapan dilakukan secara langsung di tingkat kelurahan. Hal ini sebagaimana hasil wawancara dengan wali murid pada kesimpulannya bahwa:“...pendataan penerima PIP dilakukan oleh ketua RT kemudian selang beberapa bulan kemudian dilakukan pembagian KIP dan KPS di kelurahan”.

Mengacu pada regulasi yang ada, sumber data ideal yang menjadi acuan pengusulan dan penetapan calon penerima bantuan pendidikan adalah bersumber dari basis data terpadu dari Tim Nasional Percepatan Penanggulangan Kemiskinan (TNP2K), kementrian sosial dan berdasarkan usulan kelurahan. Dalam proses pendataan calon penerima bantuan pendidikan, sekolah tidak dilibatkan lagi untuk melakukan pemuktahiran data siswa calon penerima bantuan melalui EMIS secara kontinyu karena data EMIS sendiri belum terintegrasi dengan data TNP2K. Untuk mengantisipasi tersebut Kemenag Kota Malang membentuk tim yang terintegrasi dalam bidang Penma Kemenag Kota Malang tujuan tim ini untuk membantu mengkoordinasikan dengan pihak terkait apabila terjadi masalah pendataan, dan membantu melakukan crosscheck data EMIS.

\section{Prosedur Pendataan PIP}

Dalam pelaksanaan sosialisasi dan pendataan penerima bantuan KIP, Dinas Pendidikan melakukan koordinasi dan sinkronisasi data dengan berbagai pihak. Namun koordinasi yang dilakukan masih dirasakan kurang. Kedepannya diharapkan agar terkoordinir dengan baik 
sehingga data yang diperoleh terstruktur dan terperinci serta tepat sasaran. Sedangkan berkaitan dengan upaya menjaring anak usia sekolah $(6$ - 21) yang tidak bersekolah agar kembali bersekolah Kemenag Kota Malang melakukan koordinasi dengan Kementerian Sosial, Kelurahan, Sekolah asal sampai ke tingkat RT dan RW.

Hal ini sesuai dengan wawancara dengan Pengelola PIP di Kemenag Kota Malang dengan inti sarinya sebagai berikut:

“...untuk mendapatkan data calon penerima PIP yang valid tentu harus melibatkan banyak pihak terutama madrasah, kelurahan dan Kemenag Kota Malang, alasannya karena lebih paham terhadap kondisi sosial siswa..."

Hasil wawancara tersebut memberikan gambaran bahwa prosedur pendataan idealnya harus dilakukan secara sistematis mulai dari tingkat kelurahan karena pihak kelurahan tahu betul status sosial warganya, kemudian diverifikasi langsung oleh pihak sekolah dimana calon penerima PIP belajar dan adapun pihak Kemenag Kota Malang sebagai leading sektor ditingkat daerah memiliki informasi yang beragam dan valid terhadap siswa binaannya. Dengan demikian, keterpaduan peran stakeholders terkait perlu disinergikan kembali melalui tim verifikasi bersama baik ditingkat Kemenag Kota malang maupun di tingkat satuan MI.

Sebagaimana hasil penelitian menunjukkan bahwa masing-masing 50\% responden menjawab setuju bahwa ditingkat satuan MI, Kemenag Kota Malang, dan Pemerintahan Kelurahan telah membentuk tim verifikasi data penerima PIP, adapun sisanya 50\% responden masih ragu-ragu. Data ini menunjukkan bahwa masyarakat umumnya masih kebingungan dalam proses pendataan yang dilakukan selama ini, apalagi mekanisme pendataan yang dilakaukan selama ini masih bersifat parsial sesuai dengan kebutuhan masing-masing institusi terkait.

\section{Validitas Data}

Validitas data merupakan faktor penting dari keberhasilan program. Idealnya, data setiap penerima PIP berbasis by name by adress. Ini penting dilakukan untuk meminimalisir terjadinya data ganda. Untuk mendapatkan data yang valid tersebut, perlu dilakukan pengumpulan data siswa miskin secara terpadu agar tepat sasaran, yang dimulai dari tingkat terkecil RT/RW, kelurahan, sekolah, bahkan samapi kota/kabupaten, dengan mensinergikan keterlibatan unsur aparat kelurahan, kepala sekolah, Kemenag Kota Malang bahkan dengan beberapa elemen penting lainnya.

Hasil penelitian menunjukkan berkaitan dengan ketepatan sasaran penerima PIP, diketemukan bahwa pihak Madrasah dan Kemenag Kota Malang tidak memiliki kewenangan mutlak terhadap usulan calon penerima PIP, karena secara teknis usulan PIP berdasarkan kriteria masyarakat yang memiliki KIP, KPS, peserta PKH, antisipasi korban bencana alam dan lain sebagainya yang telah diatur dalam petunjuk teknis yang telah disosialisasikan. Selain daripada itu, berdampak pada penentuan kuota penerima bantuana PIP. Atas dasar tersebut, sebaiknya pengelola PIP melakukan validasi data sehingga pemenuhan kuota tercapai, disisi yang lain, definisi siswa miskin yang masih universal sulit dicarikan kriterianya bahkan masingmasing tim pengelola memiliki pandangan yang beragam.

Atas definisi-definisi tersebut, secara kuantitas penerima PIP setiap tahun mengalami penurunan yang signifikan. Sebagaimana wawancara dengan pengelola PIP di Kemenag Kota Malang menyatakan bahwa dua tahun terakhir penerima PIP menurun dibandingkan tahun 2018 ke bawah. Salah satu penyebabnya adalah kurang validnya data penerima PIP, sehingga berdampak pada meningkatnya keluhan-keluhan dari masyarakat.

Umumnya keluhan yang diajukan oleh pengelola maupun pengguna PIP adalah berkaitan dengan proses penyaluran KIP/KPS/PKH maupun penyaluran dana yang terlambat. Biasanya keluhan melalui SMS atau telpon langsung ke nomor petugas., dan ada juga responden yang masih kebingungan dalam menjawab, hal ini kemungkinan disebabkan kurangnya pemahaman pengelola baik disebabkan karena jabatan baru, bahkan dilingkungan 
Jurnal Evaluasi dan Pembelajaran

Vol. 2 No. 1 Tahun 2020

kerja yang baru. Permasalahan lain yang menjadi aduan masyarakat adalah masih tingginya siswa yang berprestasi dan memiliki KIP/KPS namun belum masuk nominasi penerima bantuan dana PIP.

\section{Distribusi Kartu Indonesia Pintar (KIP)}

Hasil penelitian menunjukkan bahwa secara kuantitas pemilik dan pengguna KIP/KPS meningkat setiap tahun, namun dari aspek jumlah siswa yang terima bantuan PIP sejak tahun 2018 mengalami penurunan yang signifikan. Fakta ini terjadi karena adanya kebijakan dari pemerintah pusat dengan diberlakukan sistem kuota dan tingginya siswa yang berkategori miskin. Adapun secara praktis selama ini pembagian kartu indonesia pintar dilakukan oleh kelurahan, dan terkadang pembagian KIP di madrasah menyatu dengan pembagian KIP di sekolah formal,sesuai dengan moment kegiatan, sebut saja ketika kunjungan kerja pemerintah pusat, kunjungan kerja presiden dan menteri terkait.

Hasil penelitian juga menemukan bahwa terdapat beberapa permasalahan terkait pendisktribusian KIP antara lain: (1) Pendistribusian KIP yang tidak tepat waktu. Kondisi ini umumnya terjadi karena proses verifikasi dan pencetakan kartu yang terlambat dari pemerintah pusat. (2) Proses pencairan dana PIP terkadang tidak menggunakan KIP sebagai syarat, karena keterlambatan distribusi KIP. (3) Penggunaan KPS sebagai basis pemberian KIP yang langsung bisa dicairkan oleh siswa miskin berdampak pada tidak terkontrolnya proses verifikasi dan pencairan dana. Hal ini terjadi karena siswa penerima PIP tidak diwajibkan untuk melapor kepada Sekolah setelah menerima dana PIP, dan pihak Bank juga tidak memberikan tembusan data tanda terima siswa miskin yang telah mencairkan dana PIP. Walaupun terkadang pihak bank penyalur mensyaratkan supaya untuk mencairkan dana PIP, setiap penerima PIP menunjuk/membawa surat rekomendasi pencairan dana PIP dari sekolah. (5) Ditemukan juga, bahwa terdapat siswa yang masuk kategori penerima PIP namun karena tidak memiliki KIP dan KPS. (6) Data pokok penerima KIP dan KPS yang belum valid dan reliabel, karena Adanya ketidakseragaman informasi data di KPS (ada yang ditulis nama ibu, nama ayah dan nama anakanak, tetapi ada juga yang ditulis nama orangtua dan nama anak-anak saja). Ada yang hanya mencantumkan 2 anak saja, sedangkan siswa adalah anak ketiga tidak tercantum dalam KPS., dan (7) Tidak ada kejelasan alur pendistribusian KIP dan KPS. Sehingga Kepala Sekolah tidak tahu bagaimana mendapatkan KPS, padahal banyak siswa miskin di sekolah itu. Padahal di lain pihak kepemilikan KPS merupakan prioritas utama bagi penentuan siswa penerima PIP. Di dalam Panduan dan Petunjuk Teknis yang tersedia, pembahasan KPS hanya sebatas informasi bahwa prioritas pertama penerima BSM adalah pemilik KPS, serta informasi terkait bentuk format KPS. Namun informasi berkenaan dengan: apakah KPS; bagaimana memperoleh KPS; mengapa memiliki KPS; kapan memiliki KPS; dimana bisa memperoleh KPS tidak dijelaskan secara detil.

\section{Pelaporan Hasil Pendataan}

Seperti yang diulas sebelumnya, bahwa pendataan PIP sejak tahun 2018 sampai sekarang terpusat di Kemensos, sehingga pihak Kemenag Kota Malang tidak melakukan pelaporan hasil pendataan. Adapun upaya yang terus dilakukan untuk mengimbangi proses pendataan yakni dengan menghimbau kepada seluruh madrasah untuk melengkapi data EMIS Kemenag. Hal ini sebagaimana hasil wawancara dengan pengelola PIP di tingkat Kemenag Kota Malang yang mengatakan bahwa "jika dibandingkan tahun sebelum 2018, pendataan dilakukan dengan baik, terprogram dan tepat waktu." Kondisi ini disebabkan dengan tidak adanya tanggungjawab mutlak yang dibebankan ke Kemenag Kota Malang, sehingga teknis kerjanya bersifat koordinasi, dimana koordinasi ketika terdapat informasi yang berkaitan dengan pencairan dana PIP dan permasalahan kendala yang dihadapi dalam pencairan dana PIP. 
Jurnal Evaluasi dan Pembelajaran

Vol. 2 No. 1 Tahun 2020

\section{Komponen Proses}

\section{Pengelolaan Basis Data}

Hasil penelitian menunjukkan bahwa pengelolaan basis data PIP dilakukan oleh Kementerian Sosial Republik Indonesia dan berkoordinasi dengan TNP2K. Dengan asumsi bahwa pendataan PIP dilakukan secara terpadu dengan Program Keluarga Harapan dan program kemensos lainnya. Karena pola pendataan terpusat di bawah tanggungjawab Kemensos, maka Kemenag Kota Malang tidak tahu sama sekali terkait mekanisme dan teknik pendataan PIP di Madrasah Ibtidaiyah, dan terkadang Kemenag Kota Malang tidak mengetahui jumlah usulan penerima PIP. Oleh karena itu, dapat diasumsikan bahwa pengelolaan data PIP belum terlihat peningkatan kinerja pada sistem pendataan dibandingkan sebelum pendataan dikelola oleh Kemenag RI.

Kondisi idealnya dalam proses pendataan PIP secara nasional dilakukan dengan mengoptimalkan Basis Data Terpadu TNP2K, yang menjadi pijakan menentukan calon penerima PIP, disisi lain basis data dari Kemenag RI maupun Kemensos RI berdasarkan hasil verifikasi secara akurat dan berkala by name by address; serta keterpaduan database penerima PIP dari madrasah, badan Pusat Statistik, unsur Kemanag Kota Malang, bahkan pelibatan aparat desa.

Keterpaduan tiga sumber pendataan terpadu tersebut, selaras dengan kutipan wawancara dengan pengelola PIP ditingkat Kemenag Kota Malang yang menyatakan bahwa "sejak adanya pendataan yang bersifat terpusat oleh Kemensos, Kemenag Kota Malang mengalami kesulitan untuk mengakses data penerima PIP yang valid". Kondisi ini perlu adanya perbaikan dalam proses pendataan dengan menggunakan pendekatan seperti optimalisasi Basis Data Terpadu dari TNP2K, optimalisasi data yang berasal dari satuan madrasah, dan optimalisasi data EMIS dari Kemenag.

Berdasarkan hasil penelitian permasalahan umum yang dihadapi dalam proses pendataan sebagai berikut:

a. Semenjak pengelolaan PIP bersifat terpusat di Kemensos proses pendataan PIP berbeda dengan data siswa miskin yang berada dalam koordinasi Kemenag. Kondisi ini diperkuat dengan pendapat responden yang mengatakan usulan penerima PIP dari pendataan Kemensos tidak tepat sasaran karena ada beberapa siswa yang dianggap oleh sekolah mampu tapi mempunyai kartu PIP. Sedangkan ada siswa yang benar-benar membutuhkan dan miskin tidak mendapatkan kartu PIP. Hal ini menimbulkan kesalahpahaman antara orang tua siswa dan sekolah dan pihak Kemenag Kota Malang.

b. Para pengelola PIP masih sulit untuk mengakses atau mendapatkan data penerima KPS di TNP2K.

c. Basis Data Terpadu yang ada sulit diakses karena berada di TNP2K. Data tersebut tidak terbuka. Setiap institusi yang menginginkan data tersebut sebenarnya bisa memperoleh melalui CD dan ada password nya. Institusi harus mengajukan program-nya, maka TNP2K akan memberikan datanya secara langsung. Sulitnya akses data ke TNP2K karena menghindari pihak-pihak tertentu yang menyalahgunakan data tersebut untuk kepentingankepentingan seperti politik sehingga selalu diprotect (dilindungi).

d. Hampir di semua satuan pendidikan madrasah yang disurvei tidak memiliki pemahaman tentang Basis Data Terpadu yang dikelola oleh TNP2K.

e. Satuan Pendidikan Madrasah dan Kemenag Kota Malang juga belum memiliki database penerima PIP yang akurat, dan diverifikasi secara berkala.

f. Pihak satuan madrasah kesulitan mencari data siswa miskin karena tidak adanya kejelasan petunjuk teknis terkait kriteria siswa miskin yang berhak menerima PIP. Hal inilah yang menyebabkan perbedaan pilihan nama antara sekolah dan pengelola PIP di pusat yang terkadang memunculkan kasus nama ganda 
g. Satuan madrasah mengalami kesulitan dalam memverifikasi data PIP karena selama ini sekolah hanya langsung menerima daftar nama-nama penerima PIP yang berasal dari Kemenag Kota Malang dan terkadang satuan madrasah kebingungan terkait mekanisme penetapan penerima PIP.

h. Terjadinya miskomunikasi antara Bank Penyalur dengan pengelola PIP ditingkat Kemenag Kota Malang juga berdampak pada ketidakterpaduan database penerima PIP, misalnya dalam kasus terjadinya penumpukan data di akhir tahun. Informasi data yang diterima Bank Penyalur dari pusat terlambat, Hal ini menimbulkan masalah data ganda.

i. Bank menerima data penerima PIP langsung dari pusat. Ada miskomunikasi antara Bank dengan Kemenag Kota Malang, karena ternyata Kemenag Kota tidak memperoleh data tersebut, dan orang tua datang langsung ke Bank menanyakan perihal tersebut .

j. Tidak pernah ada laporan pertanggungjawaban oleh pihak Pengelola PIP di Kemenag kota Malang ke pemerintah pusat, karena berkaitan dengan kewajiban mutlak pengelola di daerah.

\section{Sosialisasi dan Koordinasi PIP}

Hasil penelitian menunjukkan bahwa belum terlihat adanya sosialisasi khusus yang mengukur kinerja Program Indonesia Pintar,adapun penyampaian informasi terkait PIP diperoleh melalui kegiatan lain seperti workshop kurikulum, pembagian bantuan dan lain sebagainya. Hal ini cukup berbeda ketika program masih di bawah koordinasi langsung Kemenag Kota Malang, dimana proses sosialisasi dilakukan secara baik, sitematis dan masif yang membahas khusus terkait program Indonesia Pintar, yang melibatkan unsur dari Penma Kemenag Kota Malang, unsur pengelola sekolah, siswa, wali murid, dan lembaga penyalur. Hal ini tercermin dalam data penelitian yang menunjukkan bahwa sebanyak 75,5\% responden menyatakan bahwa mereka belum pernah memperoleh sosialisasi sama sekali, adapun sosialisasi yang dialami sangat langka dan kurang berkesan atau tidak memperoleh pemahaman dari proses sosialisasi tersebut, sehingga mereka tidak ingat. Disisi lain, terdapat 24,5\% responden menyatakan terdapat sosialisasi terkait program yang dilakukan oleh pihak Kemenag Kota Malang dengan materi terkait pencairan dana PIP. Mayoritas menyatakan bahwa sosialisasi dilakukan secara tatap muka. Dari sosialisasi tersebut, 64,3\% diantaranya menyatakan sosialisasi dilakukan tanpa sarana pendukung, dan 35,7\% menyatakan didukung oleh sarana sosialisasi melalui unduh secara mandiri petunjuk teknis pelaksanaan PIP melalui webside Kemenag Kota Malang.

Hasil penelitian ini sinkron dengan hasil wawancara dengan pengelola PIP ditingkat Kemenag Kota Malang dimana:

“...sejak PIP dikelola oleh Kementerian Sosial Republik Indonesia proses sosialisasi dan koordinasi dari Kemenag Kota Malang hanya terbatas pada informasi pencairan dana PIP itupun terkadang pengelola mendapatkan informasi dari sesama pengelola di tingkat Kemenag".

Informasi lain yang diperoleh, umumnya informasi terkait PIP disisipkan pada kegiatan lain, karena belum ada dana khusus untuk mensosialisasikan PIP. Selain itu, sosialisasi dilakukan satu arah sehingga belum terwujud pemahaman yang komprehensif karena tidak dilakukan evaluasi apakah dipahami oleh peserta. Sosialisasi pada umumnya tidak dilengkapi bahan pendukung.

Dengan demikian, sosialisasi terkait PIP oleh Kemenag Kota Malang belum dilakukan secara intensif hal ini disebabkan keterbatasan peran dan fungsi pengelola PIP ditingkat Kemenag Kota Malang karena dari sistem manajemen Kemenag Kota Malang bersifat koordinasi dengan Kemensos, dimana sejak tahun 2018, pengelolaan PIP terkoordinir oleh Kemensos RI. Selain itu juga, kalaupun dilakukan sosialisasi dihadapkan dengan keterbatasan 
waktu dan jumlah sumber daya manusia pengelola PIP ditingkat Kemenag Kota Malang yang sedikit sedangkan lembaga sasaran dan peserta terlalu banyak mengakibatkan kegiatan sosialisasi tidak optimal, disisi lain, hampir tidak ada sosialisasi mengenai PIP dari Pusat, yang ada hanya selebaran-selebaran dan telpon himbauan yang diterima oleh Kemenag Kota Malang kemudian lalu disampaikan ke sekolah-sekolah.

Jadi, dapat disimpulkan bahwa sosialisasi dan koordinasi PIP belum brjalan dengan baik. Hal ini ditenggarai karena Kemenag Kota Malang tidak mempunyai kewenangan penuh dalam PIP, selain itu tidak adanya anggaran khusus untuk kegiatan sosialisasi, bahkan sosialisasi selalu dilakukan setelah program berjalan, selalu terlambat diduga karena anggaran turun terlambat. Hal ini juga menjadi faktor penghambat sosialisasi. Demikian pula Bank Penyalur belum mendapatkan sosialisasi secara detail, sehingga berdampak pada keterlambatan pencairan dana PIP ke penerima program. Apabila mengacu pada mekanisme sosialisasi PIP sebelumnya idealnya sosialisasi dilakukan secara berjenjang mulai dari pusat ke daerah, dan dari daerah sampai ke penerima dan lembaga penyalur.

\section{Pencairan dana PIP}

Hasil penelitian menunjukkan $100 \%$ responden menjawab pencairan dana PIP tepat waktu. Ini berarti bahwa tidak ada kesenjangan waktu antara kebutuhan dan penerimaan dana PIP. Walaupun demikian adanya kadang ada masalah dalam proses pencairan dana PIP, hasil wawancara dengan pengelola PIP di Kantor Kemenag Kota Malang bahwa:

“...berdasarkan pengalaman pihak Bank memberlakukan aturan tambahan berupa setiap siswa yang mau mencairkan dana PIP wajib melampirkan surat rekomendasi dari sekolah, dan didapati juga keterlambatan pencairan disebabkan oleh adanya nomor rekening ganda, dimana nomor rekening yang dibuku tabungan siswa berbeda dengan daftar nomor rekening yang diteriam oleh pihak bank..."

Berdasarkan informasi tersebut, dapat diidentifikasi permasalahan umum berkaitan dengan pencairan dana PIP sebagai berikut:

(a) Pengelola PIP di Kantor Kemenag Kota Malang terlambat menerima tembusan SK daftar penerima PIP, sehingga tidak dapat secara pro aktif menginformasikan penerima bantuan PIP untuk memproses pencairan dana PIP.

(b) Informasi terkait pencairan dana bagi siswa penerima PIP sepenuhnya bergantung pada informasi yang disampaikan oleh Bank Penyalur. Ketika surat pencairan dari Pusat terbit, karena responsif dari bank penyalur lamban maka proses pencairanpun terhambat.

(c) Terdapat siswa yang tidak bisa mencairkan dana PIP karena faktor meninggal dunia, pindah domisili, dan telah menjadi alumni, padahal dana bantuan tersebut masih mengendap di Bank Penyalur.

(d) Selain itu juga ada temuan kepala sekolah tidak tahu adanya pencairan dana PIP, mereka baru mengetahui ketika orangtua penerima PIP yang menerima transfer dana.

\section{Monitoring dan Evaluasi}

Untuk mengetahui keberhasilan pelaksanaan PIP idealnya harus dilakukan monitoring dan evaluasi, namun implementasinya selama ini jarang dilakukan monitoring dan evaluasi PIP oleh Pengelola di Kantor Kemenag Kota Malang. Penyebab ini terjadi karena sesuatu program yang dimonitoring dan di evaluasi adalah program yang dikelola dan menjadi tanggungjawab mutlak dari yang melakukan monitoring, dalam hal ini, karena PIP bukan tanggungjawab mutlak Kemenag Kota Malang. Harusnya yang melakukan monitoring dan evaluasi adalah Kemensos yang bekerjasama dengan TNP2K. Selama ini yang dilakukan di Kota Malang 
adalah berkaitan dengan koordinasi dengan pihak terkait berdasarkan masalah prioritas yang ada seperti keluhan masyarakat tentang pendataan, dan keluhan pencairan.

Untuk mengkoordinir berbagai keluhan dan masukan masyarakat terkait pelaksanaan PIP, Kantor Kemenag Kota Malang membuka layanan pengaduan melalui pesan singkat (SMS). Persoalan yang paling sering dikeluahkan masyarakat adalah pada proses penyaluran dana bantuan pendidikannya. Pengaduan-pengaduan tersebut berasal dari sekolah, siswa, dan orang tua siswa. Bahan aduan lain penerima PIP tidak bisa mencairkan dana karena nama siswa tidak sama dengan yang terdaftar di buku tabungan, ID rekening tidak sama, langkah antisipatif untuk perbaikan pelaksanaan PIP supaya dilakukan sinkronisasi dengan lembaga penyalur sehingga data penerima dana bantuan diinformasikan ke pihat Dinas Sosial dan Kemenag Kota Malang.

\section{Komponen Produk}

\section{Prestasi Penerima PIP}

Dari sekian responden yang ada, semuanya tidak mengisi butir kuesioner yang berkaitan dengan peningkatan mutu pendidikan di MI dengan adanya PIP. Kondisi demikian memberikan petunjuk bahwa pengelola PIP meragukan asumsi bahwa PIP berkorelasi terhadap peningkatan prestasi. Padahal berdasarkan hasil wawancara dengan wali murid mengatakan bahwa secara umum bantuan PIP belum mampu mengantarkan anak-anaknya untuk menjadi anak yang berprestasi. Informasi yang didapat bahwa bantuan PIP seharusnya bukan hanya terbatas uang operasioal sehari-hari dalam istilah wali murid "uang saku" karena pendidikan mwembutuhkan investasi yang besar dan lama.

\section{Kompetensi Penerima PIP}

Hasil penelitian menunjukkan bahwa bantuan dana PIP tidak memiliki hubungan yang spesifik dengan kompetensi penerima PIP. Kompetensi yang ditawarkan dalam riset ini berkaitan dengan motivasi sekolah setiap penerima PIP. Hasil wawancara dengan wali murid memberikan informasi bahwa:

'...dengan adanya PIP ini, anak-anak kami termotivasi untuk sekolah, bukan berarti dengan adanya PIP prestasi siswa meningkat...'

Kutipan wawancara di atas, memperkuat bahwa sangat sulit mengukur kompetensi dengan bantuan dana PIP. Umumnya siswa yang mendapat PIP sangat aktif dalam kegiatan ekstrakurikuler dan tidak sedikit yang mendapat predikat yang baik di sekolah. Hal ini sesuai dengan wawancara dengan wali murid sebagai berikut:

“...secara umum tidak ada perbedaan yang menonjol dari aspek akademik anak kami ketika sebelum maupun sesudah menerima bantuan dana PIP, karena menurut kami PIP ini hanya membantu dari aspek pembiayaan saja, bila ingin meningkatkan prestasi pemerintah harusnya menganggarkan anggaran peningkatan mutu...”

Kutipan wawancara di atas memberikan informasi bahwa secara umum adanya pembiayaan PIP tidak memberikan dampak signifikan terhadap peningkatan kompetensi anak, walaupun secara normatif anak-anak aktif mengikuti proses kegiatan ekstra kurikuler yang telah terjadwal.

Dengan demikian, hal-hal yang perlu dilakukan oleh pemerintah untuk meningkatkan kompetensi siswa yang menerima bantuan PIP antara lain sebagai berikut: (1). Mengalokasikan dana tambahan khusus peningkatan kompetensi; (2) Merumuskan kebijakan yang bersifat sentralistik bahwa pemerintah melalui kebijakan sekolah perlu meningkatkan program pengayaan bagi anak-anak yang menerima bantuan PIP; (3) Perlu adanya komitmen bersama 
Jurnal Evaluasi dan Pembelajaran

Vol. 2 No. 1 Tahun 2020

antara pihak sekolah dengan orang tua siswa, sehingga muatan kurikulum yang diajarkan disekolah, perlu ditindaklanjuti oleh orang tua dalam kehidupan sehari-hari.

\section{Kepuasan Pengelola PIP}

Secara kharfiah, tingkat kepuasan manusia sulit diukur dengan pendekatan apapun bila mengacu pada aspek kebutuhan, karena prinsipnya kebutuhan manusia tak terbatas. Namun dalam hal PIP secara umum sudah berjalan dengan baik dengan kategori respon masyarakat memuaskan. Hal ini sesuai dengan data lapangan dapat ditujukkan sebagai berikut:

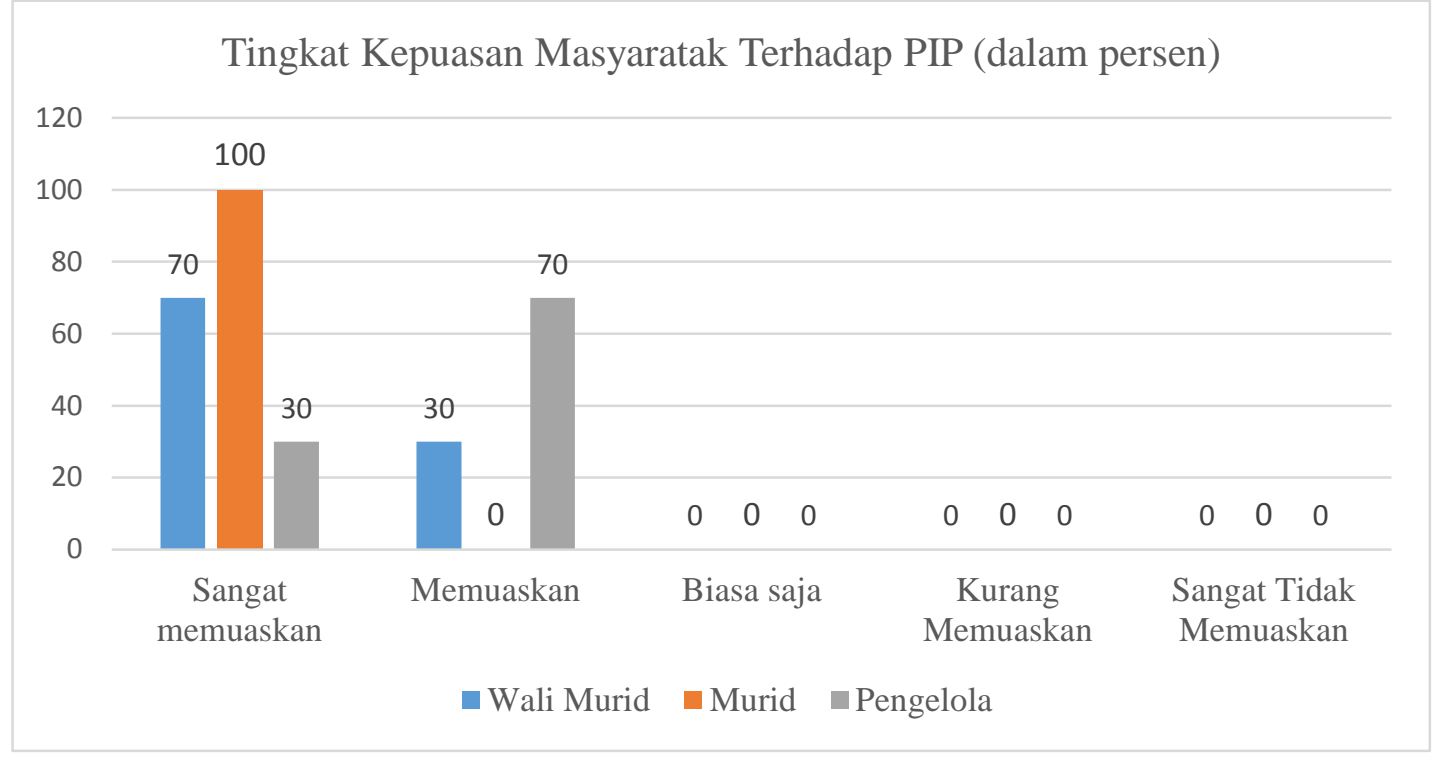

Gambar. 4 Tingkat Kepuasan Masyaratat Terhadap PIP

Berdasarkan data di atas, dapat disimpulkan bahwa masyarakat puas dengan PIP dari aspek pendanaan pembiayaan, namun dalam proses pendataan, penyaluran KIP maupun dana PIP perlu diperbaiki kembali. Hal ini menyangkut keberlangsungan suatu program. Disisi lain, proses sosialisasi, koordinasi dan monitoring perlu diintensifkan kembali guna mendapatkan relevansi suatu program dengan mutu pendidikan yang dicita-citakan.

\section{Komponen Outcome}

\section{Manfaat dan Keberlangsungan Bantuan}

Hasil penelitian menunjukkan bahwa 100\% responden berpendapat PIP bermanfaat bagi siswa dan madrasah. Kebermanfaatan PIP bagi siswa untuk mengurangi beban pembiayaan pendidikan, dan terkadang ditemukan sekolah menggratiskan secara penuh biaya pendidikan khusus peserta KIP, KPS maupun PKH. Namun karena keterbatasan alokasi anggaran sehingga ditemukan juga pemilik KIP, KPS maupun PKH tidak mendapatkan bantuan dana PIP setiap tahun secara berkesinambungan, karena setiap sekolah memiliki kebijakan tersendiri, sebut saja berbasis pemerataan bagi penerima PIP. Disisi lain, terdapat juga responden berpendapat bahwa besaran alokasi dana PIP untuk siswa belum mampu menutupi besaran biaya pendidikan yang dikeluarkan oleh siswa, dan biaya bantuan PIP hanya terbatas untuk pengganti uang saku, namun secara umum penerima PIP bersyukur bahwa bantuan PIP yang mereka terima berguna untuk membeli buku, baju seragam, transportasi ke sekolah, uang saku, membeli ATK, dan membayar SPP. Sebagaimana hasil penelitian dapat ditunjukkan dengan gambar berikut: 


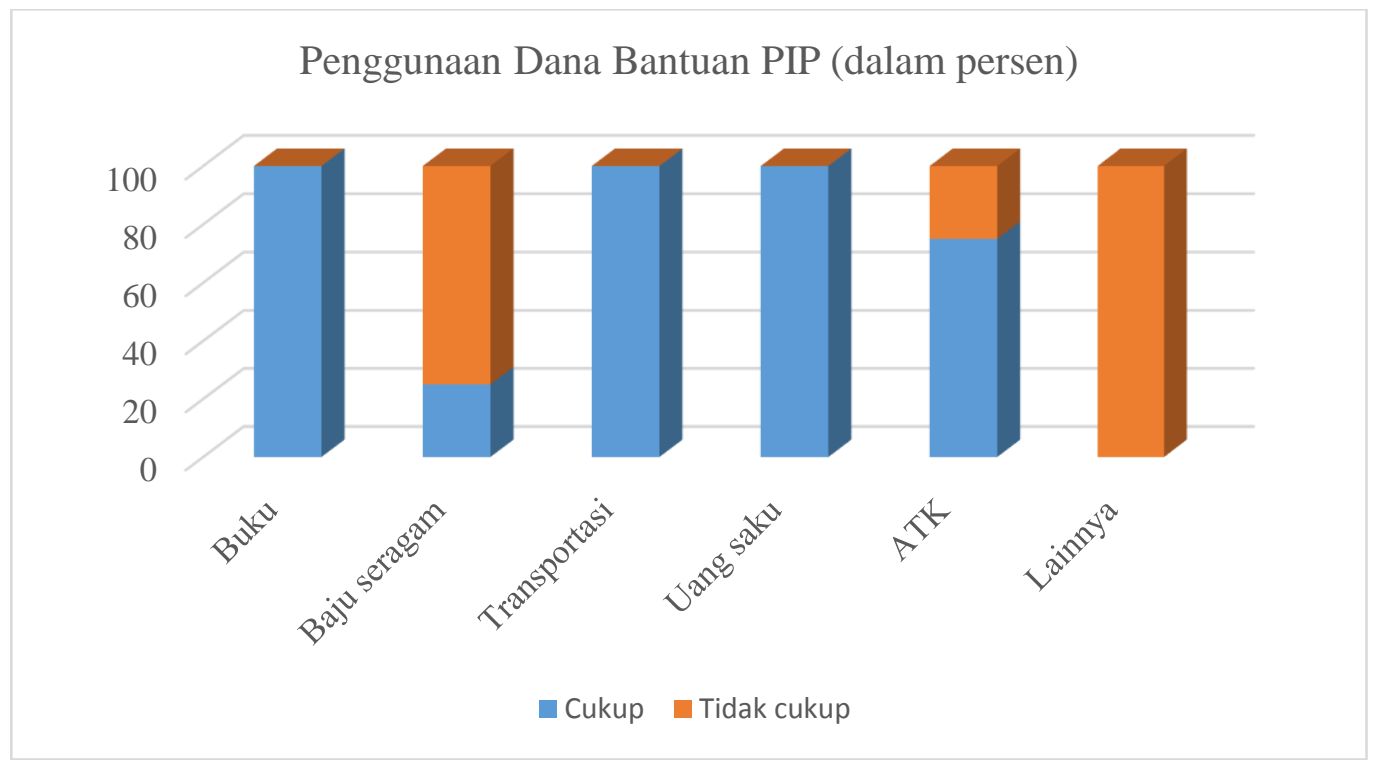

Gambar 5. Penggunaan Dana Bantuan PIP

Berdasarkan temuan di atas ternyata dana PIP belum mampu memenuhi kebutuhan operasional dasar siswa, dalam hal ini pemenuhan baju seragam baru berada pada kisaran $25 \%$, dan pembelian ATK sebesar 75\%. Besaran PIP yang masih relatif kecil ini sangat dirasakan oleh penerima, indikatornya bahwa untuk pemenuhan kebutuhan lain seperti uang makanan dan minuman tambahan belum dapat diakomodir sebagai komponen biaya bantuan PIP, sebagaimana ditunjukkan pada gambar bahwa $100 \%$ responden berpandangan bahwa dana PIP yang diterima belum dapat menjangkau biaya lainnya seperti untuk membeli makanan dan minuman, membeli pulsa dan lain sebagainya.

Temuan lain dari penelitian ini, adanya ketidaksinambungan penerima PIP setiap tahun sehingga berdampak pada menurunnya jumlah penerima dana PIP setiap tahun. Hal ini disebabkan alokasi kuota penerima PIP yang terbatas dibandingkan dengan calon penerima PIP yang membutuhkan sehingga strategi yang diterapkan adalah berbasis pemerataan atau penerimaan bantuan PIP secara bergiliran, dengan kata lain calon penerima tahun lalu yang belum dapat akan diupayakan dapat menerima di tahun berikutnya. Selain itu, belum ada kejelasan pengelompokkan, format, dan identitas penerima PIP yang merupakan dasar kesinambungan pemberian PIP. Jadi dapat dikatakan belum ada format kesinambungan data penerima PIP yang jelas. Pergantian lembaga penyalur dari satu lembaga ke lembaga yang lain juga berdampak pada ketidaksinambungan data siswa penerima PIP.

Hasil penelitian ini bila diidentifikasi dari aspek manfaat dan keberlangsungan bantuan menunjukkan bahwa:

(a) Program PIP berdampak positif terhadap motivasi siswa walaupun dari aspek kompetensi tidak menunjukkan dampak yang biasa-biasa saja, akan tetapi disisi yang lain, dengan adanya pengalokasian dana PIP memunculkan kecemburuan sosial dari siswa lain yang tidak mendapatkan dana PIP walaupun dari segi administrasi siswa-siswa tersebut masuk dalam kategori sasaran PIP.

(b) Satuan pendidikan MI belum memformulasikan upaya strategis dan inovatif berupa kegiatan pembinaan atau pembimbingan kepada penerima dana PIP secara terstruktur dan terjadwal, hal ini disebabkan alokasi pendanaan PIP belum menyasar peningkatan mutu dan daya saing, baru terbatas pada dana tambahan operasional sekolah.

(c) Belum adanya aturan yang mengikat secara operasional sehingga siswa mempunyai tanggungjawab akademik maupun non akademik.

(d) Dampak positif lain dari PIP adalah meningkatnya angka partisipasi sekolah sehingga menurunkan angka putus sekolah. 
Jurnal Evaluasi dan Pembelajaran

Vol. 2 No. 1 Tahun 2020

\section{KESIMPULAN}

Berdasarkan hasil penelitian tersebut, maka disimpulkan bahwa: (1) Pemahaman pengelola PIP ditingkat Kantor Kemenag Kota Malang tentang regulasi PIP sangat baik. (2) Pemerintah daerah tidak menerbitkan peraturan daerah terkait alokasi dana untuk menunjang PIP. (3) Alokasi kuota PIP belum memenuhi kebutuhan kuota pengusulan calon penerima PIP (4) Program PIP telah memenuhi sasaran masyarakat miskin dengan penghasilan rata-rata 500.000 per bulan. (5) Proses pendataan dilakukan secara berjenjang namun tidak transparan, sehingga pengelola PIP kebingungan dalam proses pendataan. (6) Belum adanya peningkatan sinergitas antara unsur sekolah, aparat desa, dan Kemenag Kota Malang terkait pengumpulan data penerima PIP. (7) Belum adanya peningkatan jumlah calon penerima PIP sehingga jumlah yang diusulkan tidak sesuai dengan jumlah penerima PIP yang tetapkan. (8) Adanya peningkatan jumlah keluhan masyarakat terkait mekanisme pendataan dan pencairan dana penerima PIP. (9) Belum adanya peningkatan jumlah penerima PIP memiliki KIP. (10) Proses pendistribusian KIP telah melibatkan semua unsur seperti unsur Pemda, Sekolah, dan Lembaga Mitra PIP. (11) Belum adanya peningkatan pelaporan hasil pendataan secara berkala dan tepat waktu. (12) Kemenag Kota Malang tidak memiliki basis data PIP yang secara terbuka dapat diakses oleh masyarakat. (13) Kemenag Kota Malang belum intensif melakukan sosialisasi dan koordinasi terkait PIP yang melibatkan seluruh mitra PIP. (14) Koordinasi antara Kemenag Kota Malang, pihak sekolah, dan lembaga yang mencairkan dana PIP berjalan dengan baik. (15) Pencairan dana PIP tidak tepat waktu, namun jumlah dana yang diterima secara utuh. (16) Belum adanya peningkatan kegiatan monitoring dan evaluasi PIP dengan melibatkan lembaga independent. (17) Program Indonesia Pintar secara langsung tidak berdampak terhadap prestasi belajar siswa. (18) PIP belum berdampak positif terhadap kompetensi akademik dan non akademik siswa. (19) Adanya peningkatan kepuasan pengelola terhadap pelaksanaan PIP. (20) Tidak semua pemilik KIP menerima bantuan dana PIP untuk menunjang operasional pendidikan. (21) Tidak adanya peningkatan jumlah penerima dana PIP setiap tahun baik dalam satu jenjang pendidikan maupun lintas jenjang pendidikan., dan (22) Meningkatnya angka partisipasi sekolah anak usia 6-12 tahun di Kota Malang.

\section{REKOMENDASI}

Berdasarkan hasil penelitian tersebut, maka dapat direkomendasikan sebagai masukan sebagai berikut: (1) Kebijakan terkait pengelolaan data PIP oleh Kemensos diharapkan untuk ditinjau ulang, karena berdampak kepada manajemen tata kelola PIP oleh Kantor Kemenag Kota Malang, dengan kata lain, bahwa pengelolaan PIP diberikan tanggungjawab penuh ke Kemenag. (2) Perlu adanya penegasan pihak terkait yang bertanggungjawab penuh terhadap sistem sosialisasi yang melibatkan semua unsur terkait sepertiKemenag Kota Malang, satuan MI, lembaga penyalur, aparat desa dan masyarakat. (3) Sosialisasi dilakukan secara intensif tentang informasi bahwa penerima tetap pemegang KIP/KPS untuk menghindari keragaman persepsi. (4) Perlu adanya sistem yang menjamin terwujudnya koordinasi di dalam upaya memvalidasi dan mensinergikan data pengusul dan penerima bantuan dana PIP. (5) Perlu adanya kebijakan, sistem, pendelegasian wewenang dan indikator yang mengukur dalam proses monitoring dan evaluasi pelaksanaan PIP. (6) Pemberdayaan dan optimalisasi sistem EMIS di Kemenag secara masif, sitematis, dengan mengintegrasikan data dari Kemensos dan TNP2K. (7) Sistem pendataan di EMIS perlu diupdate dan dilengkapi guna menjaga akurasi data secara menyeluruh. (8) Kemenag dan Madrasah diberikan kewenangan penuh dalam mengusulkan calon penerima KIP. (9) Mekanisme penerapan kebijakan penetapan kuota, yang memastikan bahwa perhitungan kuota berdasarkan rasio jumlah siswa miskin di satuan pendidikan, bukan rasio jumlah siswa di setiap satuan pendidikan.selain indeks kemiskinan. (10) Penyaluran dana bantuan yang mempertimbangkan karakteristik wilayah (perkotaan/daratan dan kepulauan) dan Efektivitas dan Efisiensi Penyalur. (11) Kebijakan tentang pengalihan dana yang retur (DO atau 
Jurnal Evaluasi dan Pembelajaran

Vol. 2 No. 1 Tahun 2020

double) kepada siswa lain, agar dana yang diterima oleh bank penyalur $100 \%$ bisa diserap. Sehingga tidak perlu dikembalikan ke Pusat karena prosesnya cukup merepotkan. (12) Sistem alur pemberian KPS/KIP yang lebih sederhana, langsung ke Sekolah dengan berkoordinasi dengan Kemenag setempat. (13) Sistem yang menjamin terwujudnya koordinasi terkait pengelolaan penyaluran dana PIP antara: Kemenag Kota, Bank Penyalur, dan Satuan Pendidikan. (14) Kebijakan terkait program pembinaan peningkatan prestasi siswa, Sistem dan sarana monitoring dan evaluasi dampak prestasi penerima PIP yang terjadwal dan terukur baik di Satuan Pendidikan maupun di Kemenag Kota Setempat. (15) Kebijakan yang mewajibkan siswa penerima dana PIP untuk meningkatkan nilai rata-rata rapornya setelah menerima bantuan, jika memungkinkan ditetapkan nilai rata-rata rapor yang harus diraih untuk memotivasi semangat belajar penerima PIP serta meningkatkan harga diri penerima PIP., dan (16) Sistem yang menegaskan kewajiban pengelola PIP di Satuan Pendidikan untuk melakukan pembinaan dan peningkatan prestasi bagi siswa penerima PIP yang dituangkan dalam panduan.

\section{DAFTAR PUSTAKA}

Bahrul Kirom. 2012. Mengukur Kinerja Pelayanan dan Kepuasan Konsumen. Bandung: Pustaka Reka Cipta.

Daniel L. Stufflebeam dan Anthony J. Shinkfield. 2007. Evaluation: Theory, Models, \& Applications. San Francisco: Jossey-Bass.

Fitzpatrick, Jody L., Blaine R. Worthen, dan James R. Sanders. 2004. Program Evaluation: Alternative Approaches and Practical Guidelines. Boston: Person Education.

Kementerian Pendidikan dan Kebudayaan. 2015. Rencana Strategis Kementerian Pendidikan dan Kebudayaan Tahun 2015-2019. Jakarta: Kementerian Pendidikan dan Kebudayaan.

Lingga Pos. Pemerintah Siapkan Rp. 9,34 Triliun Untuk PIP 2018. Edisi 4 September 2017.

Diakses tanggal 20 Februari 2018 Pukul 11.13 WIB

http://www.linggapos.com/19385_pemerintah-siapkan-rp934-triliun-untuk-pip2018.html

Marvin C. Alkin. 2011. Evaluation Essentials: From A to Z. New York: The Guilford Press.

Payaman J. Simanjuntak. 2011. Manajemen dan Evaluasi Kinerja. Jakarta: Lembaga Penerbit Fakultas Ekonomi Universitas Indonesia.

Staf Ahli Bidang Sosial dan Ekonomi Pendidikan Kementerian Pendidikan dan Kebudayaan. 2013. Optimalisasi Potensi Lembaga Pemberi Beasiswa 2013. Jakarta: Staf Ahli Bidang Sosial dan Ekonomi Pendidikan Kementerian Pendidikan dan Kebudayaan.

Tola, Burhanuddin. 2014. Evaluasi Program: Gambaran Perkembangan Sejarah Evaluasi. Bunga Rampai. Jakarta: Program Pascasarjana Universitas Negeri Jakarta.

Wirawan. 2009. Evaluasi Kinerja Sumber Daya Manusia, Teori, Aplikasi dan Penelitian. Jakarta: Salemba Empat. 